Journal of Economics and Behavioral Studies

Vol. 6, No. 5, pp. 340-350, May 2014 (ISSN: 2220-6140)

\title{
Implementation of Cooperatives' Principles on Ranked-Cooperatives, East Java 2012
}

\author{
${ }^{1}$ Wiwiek Harwiki*, ${ }^{2}$ Ruswiati Suryasaputra \\ ${ }^{1}$ Dr. Soetomo University Surabaya, Indonesia \\ 2Universiti Utara Malaysia, Malaysia \\ *harwiki@yahoo.com
}

\begin{abstract}
The purposes of this research to identify of values and cooperatives' principles on the field, to identify roles and member participation to improving cooperatives, to identify cooperatives' performance based on cooperatives' principles, and to identify problems in order to implementing the cooperatives' principles. Samples were collected amount 52 cooperatives have been assessed as the accredited cooperatives by Small Medium Enterprise and Cooperatives Office East Java. Methodology supported this research were inventory, field survey, and data analysis. Data have been analyzed and evaluated on 2 steps: grading the defined instrument and checking the supported documents given by respondents. The research findings: Cooperatives' Principles is an abstract vision which has to spell out how these Principles are to be practiced. The Success programmes as a way to implementing Cooperatives' Principles that guiding the operation of organization. The product of all cooperatives surveyed was not specific products and need innovation products. Better service for members to survive among other cooperatives. To implement Cooperatives' Principles, there were correlations between: Management Control and Members' Satisfaction, Boards' Performance and Members' Satisfaction, Well-controlled Administration and Members' Satisfaction, Capital Structure and Members' Satisfaction, Unit Business and Members' Satisfaction, Training \& Education and Members' Satisfaction, Cohesiveness and Members' Satisfaction.
\end{abstract}

Keywords: Cooperatives, Accredited Cooperatives, Cooperatives' Principles Implementation

\section{Introduction}

According to World Bank, Indonesia is one of many poorest countries worldwide. Poverty is scattered over islands. Billions people live above poverty line. They live without mission, and hopeless. Number of poverty people is more than 31 billion. The greatest number is East Java (5, 1 billion), but comparing with the year in advance (2010) the number (5, 4 billion) is decreasing (Central Bureau of Statistic, 2011). Although Hansen (1993) said difficult to prove that cooperatives have contributed significantly to employment and to the alleviation of the consequences of poverty, The Regional Government in East Java supported and recognized Cooperatives and Small Medium Enterprises and as a crucial way against poverty economically as told by Rachbini (1988). East Java as one of the biggest Province in Indonesia has more than 4,2 millions Small Medium Enterprises, number of Cooperatives was 29.145 units and absorbed man power as many as 75.430 people, with total business volume of about 26,29 trillions rupiahs in 2011 (Central Bureau of Statistic, 2012). Cooperatives can be formed for a number of reasons. As long as there are common economic, social and/or cultural needs for which people feel it advantageous to join together and form enterprises that are jointly owned and democratically controlled, cooperatives are beneficial. Cooperatives can be classified in different ways based on a number of criteria such as the types of groups served, geographic territory served, industry, sector, functions performed, membership structure, legal status, and financial structure (Krivokapic-Skoko, 2002; Wissman, 1997).

Cooperatives strive to empower both employees and members with regular education and training. Furthermore, each year the cooperative encourages members to participate in many social economy activities. This social activity is intended to strengthen the relationship between members and emphasize the family atmosphere within the cooperatives. Indonesian government has increasingly recognized the contribution that Cooperatives can make to reducing poverty and empowering disadvantaged groups. Many reasons of conducting research on Accredited Cooperatives as follows: (1) Only 17,8\% of 29,145 units (52 
units) as Accredited Cooperatives shows not only so rigid and competitive, but also as a big opportunity to be selected for another Cooperatives in East Java, (2) The result of implementation of Cooperatives' Principles on Accredited Cooperatives research beneficial as a trigger for ordinary other Cooperatives hopefully, and (3) Indirectly, the result of this research will firm the strength of national economy within Cooperatives as one of supporting tools and rising the economy ability of members on increasing their social and economy wealthier (Cooperatives Constitution, 1992).

Actually, Accredited Cooperatives is a cooperatives has been assessed by Cooperatives and Small Medium Enterprises Office, East Java Region based on the Policy of State Minister of Cooperatives and Small Medium Enterprises No. 22/PEM/M.KUMK/IV/2007 and had been completed by Policy of State Minister of Cooperatives and Small Medium Enterprises No. 06/PER/M.KUMK/III/2008 with these conditions: 1) Having the Active Unit Business: conducting member annual meeting, auditing, planning, organizing, actuating, controlling, running-well business and comply to laws 2) The Better Organization Performance: the increasing of composition of capital structure, funding availability, the growth of assets, business volume, production capacities and profits; 3) Cohesiveness and Members' Participation: members involvement, risk sharing, better serving, and other quantitative measurements such as ratios of member amount, attendance on meeting, paying loan, and the beneficial of serving; 4) Serving Member Oriented: relational bonding between organization and member business, training and education activities relating to members' business, and the amount of members' businesses on its cooperatives; 5) Serving Community: pointed by the workers employable on and how far the cooperatives serviced for the society including roles on decreasing the poverty around, and 5) Contributing the Local Government: obey laws, be a good tax payer and support the local government on developing society. Furthermore, Cooperatives' Principles has been implemented on Accredited Cooperatives should be more empower to be practiced in order to increasing the meaningful of the relationship between: Management Control and Members' Satisfaction, Boards' Performance and Members' Satisfaction, Well-controlled Administration and Members' Satisfaction, Capital Structure and Members' Satisfaction, Unit Business and Members' Satisfaction, Training \& Education and Members' Satisfaction, Cohesiveness and Members' Satisfaction.

\section{Literature Review}

International Labor Organization/ILO (1992) stated that a cooperative is an association of persons who have voluntarily joined together to achieve a common end through the formation of a democratically controlled organization, making equitable contributions to the capital required and accepting a fair share of the risks and benefits of the undertaking in which members actively participate, in line with The International Cooperative Association/ICA (1995) defined cooperative as an autonomous association of persons united voluntarily to meet their common economic, social and cultural needs and aspiration through a jointly owned and democratically controlled enterprise. According to Indonesian Cooperatives Constitution (1992), cooperatives defined as a business entity consisting of a person or legal entity within cooperative activities based on the principles of cooperation as well as economic movement based on the kinship principle. It is clear that cooperatives have different achievement and improvement levels among the countries or societies. There is no doubt that this difference is directly related with the level of social "Membership Culture" which shows the awareness and capacity of the societies to deal with - overcome the challenges jointly, in cooperation or in collaboration (Altay, 2007). In the past 150 years since the first cooperative enterprises emerged out of the excesses of the industrial revolution, cooperatives have spread over 100 countries into a diverse range of sectors and activities, although cooperatives have been demonstrated to be particularly effective in agriculture. Cooperatives are now significant economic and social actors with a membership of approximately 800 million people throughout the world (Hansen, 1993).

Furthermore, addressing and implementing the cooperatives system, which is still regarded as one of the most efficient means of development today, in a rational and integrated approach will not only contribute much to manufacturers, consumers, small enterprises and other beneficiaries but also to activating the idle resources, expanding the opportunities on micro credits and financing, providing the capital stock, creating new employment areas, increasing the production, integrating the agriculture and small production fields with the industry, regulating the markets in a more positive manner, improving the entrepreneurship and the culture of running common business, increasing the social capital, sharing the capital more equally, reducing 
the poverty and thus helping our country to develop as a whole. Moreover, problems such as deepening of the financial crisis, increase in unemployment, social exclusion and increase in poverty in the world during the 1980s have featured new solution seeking to the benefit of the society. The developments in the globalization process, shrinking of the public sector as a result of privatization, the inability of the public sector to solve the increasing social problems and the private sector attitude of addressing the social problems only to seek profits by its very nature have revived a new economic, social and political approach called "social economy" or "the third system" or "the third sector" (Kostekly, 2005). As stated in article 4 number 25 of Indonesian Cooperatives Constitution (1992), the function and roles of Indonesian Cooperatives as follow: 1) Build and develop the potential and the economy ability's member in particular, and for society in general to improve their social economy well-being; 2) Participate to enhancing the quality of human life and society, 3) strengthen the national economy condition within Cooperatives as the foundation, and 4). Build and develop the national economy as a joint business based on kinship value and democracy economy.

Cooperatives are faced with different challenges and opportunities, adapting their types to variables such as the target groups served, geographic territory served, functions performed, membership structure, legal status, financial structure, and controlling entity (Krivokapic-Skoko, 2002; Wissman, 1997), as well as in Indonesia within some divisions are: 1). Producers' cooperatives: these businesses refer to groups of people cooperating in the agricultural arena: farming, fishing, and forestry. They may buy farm inputs, equipment, and insurance, hire managers and sales people, market and advertise together, or operate storage or processing facilities or a distribution network; 2) Work-owned cooperatives: these businesses are owned by some or all of the workers. Many workers' cooperatives are fairly small and have no separate boards of directors; everyone takes a direct role in policy making and other governance functions; 3) Consumers' cooperatives: Consumers can create a cooperative to purchase groceries, electricity or telephone service, housing, healthcare, and financial services; 4) Saving and Credit Cooperatives: through their ability to mobilize savings and make loans available to households and small-businesses and farmers, can quickly and efficiently generate positive effects on income for relatively large numbers of people and small-scale enterprises as well as create favorable impacts on employment; 5) Multi-purposes Cooperatives: these business refer to various economy activities such as: groceries, credit and savings, motorcycle repairing, and hospital. In Indonesia, The Principle of Cooperatives as an unity cannot be separated from cooperatives' activities have been inspired of seven operational principles (The International Co-operative Alliance, 1995) as follow: 1). Voluntary and open membership: open to all people without gender, social, racial and political or religious discrimination; 2). Democratic member control: members have equal voting rights; 3) Members' Economic Participation: members contribution in controlling the capital of their cooperatives transparently and democratically; 4) Autonomy and independence: autonomous self-help organizations controlled by their members; 5) Education, training and information: provide education and training for their members; 6) Cooperation among cooperatives: working together through local, national, regional and international structures; and 7) Concern for community: working for sustainable development of their communities.

According to Dinamika (2010) The Cooperatives' Principles describe the Cooperatives' identity including values on self-help, self-responsibility, democratic, equality, fairness, solidarity, and honestly, unfortunately in the course of principles implementation, there are some cooperatives that did not run in accordance with the values and principles since: 1 ) Cooperatives did not yet properly understand the values and principles of cooperatives; 2) Many obstacles in field made several cooperatives tempted to come out of the values and principles of cooperatives, and 3) Lack of training and education for officials and employees of cooperatives so they cannot absorb the spirit and the soul of cooperatives well. Such conditions will greatly affect the employee job satisfaction in many organizations including cooperatives, as Robbins \& Judge stated (2009) that there were 21 factors related to job satisfaction as follow: autonomy and freedom, career benefits, opportunity to advance, career development opportunities, compensation/salary, communication between employees and management, contribution to the work of the organization's objectives, feeling safe working environment, flexibility to balancing life and work issues, job security, organizational commitment, job specific training, recognition for employees' performance, the significance of the work, networking, opportunities to use abilities or skills, corporate culture, the relationship fellow employees, relationships with immediate supervisor, the work itself, and job diversity. 
Kreitner \& Kinicki (2005) suggested 5 factors influencing satisfaction as follow: 1) Need to fulfill or compliance requirements; 2 ) Discrepancies or differences: this model suggests that satisfaction is an outcome meets expectations; 3 ) Attainment value: this model states that satisfaction as results of work perception gives the fulfillment of individual work values are important; 4 ) Equity or fairness: this model suggests that satisfaction as functions of how individual justice are kept in the workplace. Satisfaction is the result of the perception how to compare the work and its inputs relatively more profitable than the ratio of outputs and other input works. Herzberg's (2003) motivation-hygiene theory identifies intrinsic motivators (e.g. achievement, recognition, the work itself) and hygiene factors which tend to be extrinsic factors (e.g. company administration, supervision, salary). Herzberg's view is that these motivators lead to job satisfaction because they satisfy an individual's need for self-actualization (Maslow, 1954; Tietjen \& Myers, 1998).

In line with theories above, Dinamika's research (2010) concluded several variables used to assess the rank of the principles' implementation as follow: 1) Management Control: is used to measure if the mechanism in the organization running correctly; 2) Members' Satisfaction: is a measure of how services supplied by a cooperatives meet or surpass customer expectation; 3) Boards' Performance: is used to measure boards' performance to conduct activities on the right system, structure, strategy, style, skill, staff, and how to share values for others; 4) Well-controlled Administration: is a measure how cooperatives provide tools (books), report, and comply the administration and financial process appropriate with Cooperatives Accountant Norms; 5) Capital Structure: is a measure of how the proportion of capital owned by cooperatives, competition ability and financial condition (financial ratios= liquidity, solvability, profitability and activity); 6) Unit Business: is used to measure business center as a profit center in organization; 7) Training \& Education: is used to measure the pattern of preparing members to become boards in the future; 8) Cohesiveness: is used to measure the amount of members' transaction, ratios of net income to rewards; ratios of the increasing of the members' amount, and ratios of increasing of the members' equity involvement.

\section{Methodology}

The research was conducted in East Java Province as a whole currently has 17 districts as the area within 52 units Accredited Cooperatives have been assessed by Cooperatives Small Medium Enterprises Office East Java Region on 2011. Population in this study includes all boards of Accredited Cooperatives consisting of 65 people have been interviewed and 52 questionnaires valid to be processed. The methodology has been conducted consist of inventory, field survey, and data analysis. Data have been analyzed and evaluated on 2 steps: grading the defined instrument and checking the supported documents given by respondents. The 3 steps in this research were: 1) data collecting; 2) data processing, and 3) analyzing survey result. Several sources used to this research as follow: 1) primary data source (interviewing the boards on questionnaires), and 2) secondary data source (references and supporting documents). The questionnaires result from interviewing has been analyzed statistically. Analyzing process on Validity and Reliability Instruments in collecting data by: 1) Convergent Validity; 2) Discriminant Validity; 3) Construct Validity; 4) 7 Kinsey Model and Service Quality Concepts

\section{Results}

Variable Management Control: 45 units (86\%) Accredited Cooperatives conducted control activity on each semester (6 months), and 7 units (14\%) once on three months. For auditing activity, 22 units (58\%) conducted by Cooperatives Controller and Independent Auditor, 30 units (42\%) conducted by Cooperatives Controller. To compete with other business, especially in global era, 50 units (96\%) prepared management strategy, but 2 units (4\%) were not. Relating to their products: a) All the cooperatives surveyed (100\%) felt confident and proud with their products, unfortunately 45 units $(86 \%)$ did not have specific products, 50 units (96\%) had the easily imitated products, and only 7 units (14\%) had specific products, and 2 units (4\%) did not have specific products, b) 48 units (92\%) sold same products with the market, 3 units (6\%) sold the little different kind of products with the market, and 1 unit $(2 \%)$ sold products that did not available in the market, c) 50 units (96\%) sold products that fit between prices and qualities, 2 units (4\%) sold products that did not appropriate between prices and qualities, d) 48 units (92\%) stated that the products were sold in accordance with members' need, and 4 units (8\%) stated that the products did not appropriate with members' need, d) 6 units (12\%) always sell products integrated with the other parties, 46 units (88\%) 
stated just sometimes, e) 18 units ( $35 \%$ ) launched 1 new product, 8 units (15\%) launched 2 new products, and 26 units (50\%) had no a new product completely.

Members' Satisfaction: In terms of satisfaction, 32 interviewees (62\%) stated that cooperatives were adequate enough, 16 interviewees (30\%) determined that cooperatives were very adequate but 4 interviewees $(8 \%)$ claimed that cooperatives less adequate. Relating to office facilities, 52 interviewees $(100 \%)$ satisfied, but there were 5 interviewees (10\%) dissatisfied with the service and 32 interviewees (61\%) satisfied with the service, 15 interviewees $(29 \%)$ very satisfied with the service. Whole interviewees $(52=100 \%)$ completely satisfied on accessing to the officer, getting the officer's attention, the knowledge of employees, courtesy, ability to provide information and officer's respond.

Variable Board Performance: 31 units (60\%) Accredited Cooperatives have Long Term Working Plan and Income and Spending Budget, 21 units (40\%) have not, but all of units (52 units=100\%) have Short Term Working Plan and Income and Spending Budget. Long term takes more than 5 years, and short term takes 1-4 years. All units (52 units $=100 \%$ ) held Members' Annual Meeting to legalize the Working Plan and Income and Spending Budget. Based on The Working Plan, 20 units (50\%) done 1-5 item programmes, 19 units (37\%) done 6-9 item programmes, and 7 units (23\%) done more than 10 item programmes. All Accredited Cooperatives have Guidance for Board Duty, there were 44 units (82\%) well conducted on decision making, 8 units $(16 \%)$ have guidance but did not conduct decision making.

Variable Well-Controlled Administration: All of the Accredited Cooperatives (52 units $=100 \%$ ) had Logistic Book to report their activities. The type of these books was: Members' Book, Book for Saving's Member, Book for Board Meeting, Book for Board List, Book for Controller, and Minutes Book. Relating to Cooperatives Information System, 49 units (94\%) had a recording and data processing, but 3 units (6\%) had not, thus 49 units ( $94 \%$ ) gave information for members completely, 50 units (98\%) gave information for advisor completely. All cooperatives surveyed (52 units $=100 \%$ ) had taxpayer identification number and retribution number, therefore it proved that all cooperatives comply with taxation and retribution and willing to pay their tax and retribution. In terms of employment, 24 units $(46 \%)$ had a larger increasing number of workforces than the year before (2011), 23 units (44\%) had the similar employment rate and 5 units (10\%) had a smaller employment rate than the previous year (2011). About wages, 30 units (57\%) stated that they pay more than regional minimum wage rate and 22 units (43\%) paid wages equal to regional minimum wage rate.

Variable Capital Structure: 49 units (94\%) Accredited Cooperatives got the capital from Compulsory Saving and more than the year before, 22 units (42\%) increases their reverse funds, but 9 units (8\%) decreasing their reverse funds. Total Assets: 48 units (92\%) increasing their total assets, but 4 units (8\%) stagnant. Comparing with the condition in the previous year (2011): a) Capital loan from the third parties (other cooperatives, banks and other financial institutions, bonds and mortgage, and other sources) have been decreased for 41 units (78\%) and 11 units (22\%) have been increased, but capital loan from inside (members' fund) were tend to fall for 15 units (28\%) and 28 units (28\%) were tend to rise. This condition reflected that cooperatives surveyed had many sources to finance their activities, b) The total assets were increased for 48 units $(92 \%)$ and 4 units (85\%) were stagnant and c) The business profit for members were increased at 48 units (92\%) and 4 units (8\%) were decreased.

Variable Unit Business: 35 units (67\%) Accredited Cooperatives had 1-3 type unit businesses, 17 (33\%) units had 4-7 type unit businesses, and from all these types businesses, 40 units (80\%) running well at 1-3 types, 11 units (20\%) running well at 4-7 types. In running business, 50 units (96\%) stated that their business linkage with members' need and 2 units (4\%) answered that their business did not associate with members' need. Almost cooperatives (50 units $=92 \%$ ) acknowledged that they sold products for nonmembers and only 4 units (8\%) sold products for members, nevertheless 48 units (92\%) confident that community surrounding well informed about their business and only 4 units (8\%) did not give the information about the business, therefore 48 units (92\%) got the good response from the public and 4 units $(8 \%)$ obtained a very good public response. 
Training \& Education: 27 units (52\%) were good on regeneration pattern, 27 units (48\%) had not generation pattern, and 30 units ( 58\%) had the recruitment system, 22 units (42\%) had no the recruitment system. All of the cooperatives surveyed (52 units $=100 \%$ ) stated that less than a half cadres became boards, means that trained cadres did not become boards, but almost cooperatives' surveyed (50 units $=96 \%$ ) had training programmes, and 2 units $(4 \%)$ had not prepared the training programme. In implementing educational programmes 43 units (82\%) determined that they could finish all programmes, but 9 units (18\%) could conduct programmes partially.

Cohesiveness: a) members' participation on sales: 24 units (46\%) stated that members' participation bigger than the number of sales, 12 units (23\%) stated smaller, and 16 units (30\%) determined that equal members' participation by the number of sales, b) membership: 50 units (96\%) determined that the number of members increased, 2 units (4\%) stated fixed, c) the amount of equity: 34 units (65\%) stated that comparing to the previous year (2010) the amount of equity in cooperatives increased, 16 units (31\%) determined fixed, and 2 units (4\%) determined decreased, d) members' participation: 31 units (60\%) stated that comparing to the previous year (2010), members' participation were greater than the year of research, 3 units (5\%) stated smaller, and 18 units (35\%) determined fixed.

\section{Management Control and Members' Satisfaction}

Table 1: Correlation between Management Control and Members' Satisfaction

Correlations

\begin{tabular}{llll}
\hline & & Management Control & Members' Satisfaction \\
\hline Management Control & Pearson Correlation & 1 & $.439^{* *}$ \\
& Sig. (2-tailed) & & .001 \\
& $\mathrm{~N}$ & 52 & 52 \\
Members' & & \\
Satisfaction & Pearson Correlation & $.439^{* *}$ & 1 \\
& Sig. (2-tailed) & .001 & \\
& $\mathrm{~N}$ & 52 & 52 \\
\hline
\end{tabular}

** Correlation is significant at the 0.01 level (2-tiled), margin error 0.05

Correlation value 0.439 with probability 0.001 and probability value smaller than the error rate $5 \%$ $(0.001<0.05)$, it can be concluded there is a correlation between Management Control and Members' Satisfaction. The coefficient is positive indicated the unidirectional relationship, means if the higher level of Management Control thus higher level on Members' Satisfaction, otherwise if the lower level on Management Control thus the lower level on Members' Satisfaction

\section{Boards' Performance and Members' Satisfaction}

Table 2: Correlation between Boards' Performance and Members' Satisfaction

Correlations

\begin{tabular}{llll}
\hline & & Boards' Performance & Members' Satisfaction \\
\hline Boards' Performance & Pearson Correlation & 1 & $.471^{* *}$ \\
& Sig. (2-tailed) & & .002 \\
& $\mathrm{~N}$ & 52 & 52 \\
\multirow{3}{*}{ Members' Satisfaction } & Pearson Correlation & $.471^{* *}$ & 1 \\
& Sig. (2-tailed) & .002 & \\
& $\mathrm{~N}$ & 52 & 52 \\
\hline
\end{tabular}

** Correlation is significant at the 0.01 level (2-tiled), margin error 0.05

Correlation value 0.471 with probability 0.002 and probability value smaller than the error rate $5 \%$ $(0.001<0.05)$, it can be concluded there is a correlation between Boards' Performance and Members' Satisfaction. The coefficient is positive indicated the unidirectional relationship, means if the higher level of 
Boards' Performance thus higher level on Members' Satisfaction, otherwise if the lower level on Boards' Performance thus the lower level on Members' Satisfaction.

Well-controlled Administration and Members' Satisfaction

Table 3: Correlation between Well-controlled Administration and Members' Satisfaction

\begin{tabular}{|c|c|c|c|}
\hline & & $\begin{array}{l}\text { Well-controlled } \\
\text { Administration }\end{array}$ & $\begin{array}{l}\text { Members' } \\
\text { Satisfaction }\end{array}$ \\
\hline Well-controlled & Pearson & & \\
\hline \multirow[t]{4}{*}{ Administration } & Correlation & 1 & $.473^{* *}$ \\
\hline & Sig. (2-tailed) & & .002 \\
\hline & $\mathrm{N}$ & 52 & 52 \\
\hline & Pearson & & \\
\hline \multirow[t]{3}{*}{ Members' Satisfaction } & Correlation & $.473^{* *}$ & 1 \\
\hline & Sig. (2-tailed) & .002 & \\
\hline & $\mathrm{N}$ & 52 & 52 \\
\hline
\end{tabular}

** Correlation is significant at the 0.01 level (2-tiled), margin error 0.05

Correlation value 0.473 with probability 0.002 and probability value smaller than the error rate $5 \%$ $(0.001<0.05)$, it can be concluded there is a correlation between Well-controlled Administration and Members' Satisfaction. The coefficient is positive indicated the unidirectional relationship, means if the higher level of Well-controlled Administration thus higher level on Members' Satisfaction, otherwise if the lower level on Well-controlled Administration thus the lower level on Members' Satisfaction.

\section{Capital Structure and Members' Satisfaction}

Table 4: Correlation between Capital Structure and Members' Satisfaction

\begin{tabular}{llll}
\hline & & Capital Structure & Members' Satisfaction \\
\hline Capital Structure & Pearson Correlation & 1 & $.457^{* *}$ \\
& Sig. (2-tailed) & & .001 \\
& $\mathrm{~N}$ & 52 & 52 \\
Members' Satisfaction & Pearson Correlation & $.457^{* *}$ & 1 \\
& Sig. (2-tailed) & .001 & \\
& $\mathrm{~N}$ & 52 & 52 \\
\hline
\end{tabular}

** Correlation is significant at the 0.01 level (2-tiled), margin error 0.05

Correlation value 0.457 with probability 0.001 and probability value smaller than the error rate $5 \%$ $(0.001<0.05)$, it can be concluded there is a correlation between Capital Structure and Members' Satisfaction. The coefficient is positive indicated the unidirectional relationship, means if the higher level of Capital Structure thus higher level on Members' Satisfaction, otherwise if the lower level on Capital Structure thus the lower level on Members' Satisfaction.

\section{Unit Business and Members' Satisfaction}

Table 5: Correlation between Unit Business and Members' Satisfaction

\begin{tabular}{llll}
\hline & & Unit Business & Members' Satisfaction \\
\hline Unit Business & Pearson Correlation & 1 & $.437^{* *}$ \\
& Sig. (2-tailed) & & .001 \\
& $\mathrm{~N}$ & 52 & 52 \\
Members' Satisfaction & Pearson Correlation & $.457^{* *}$ & 1 \\
& Sig. (2-tailed) & .001 & \\
& $\mathrm{~N}$ & 52 & 52 \\
\hline
\end{tabular}

** Correlation is significant at the 0.01 level (2-tiled), margin error 0.05 
Correlation value 0.437 with probability 0.001 and probability value smaller than the error rate $5 \%$ $(0.001<0.05)$, it can be concluded there is a correlation between Unit Business and Members' Satisfaction. The coefficient is positive indicated the unidirectional relationship, means if the higher level of Unit Business thus higher level on Members' Satisfaction, otherwise if the lower level on Unit Business thus the lower level on Members' Satisfaction.

Training \& Education and Members' Satisfaction

Table 6: Correlation between Training \& Education and Members' Satisfaction

\begin{tabular}{llll}
\hline & & Training \& Education & $\begin{array}{l}\text { Members' } \\
\text { Satisfaction }\end{array}$ \\
\hline Training \& Education & Pearson Correlation & 1 & $.468^{* *}$ \\
& Sig. (2-tailed) & & .003 \\
& $\mathrm{~N}$ & 52 & 52 \\
Members' Satisfaction & Pearson Correlation & $.468^{* *}$ & 1 \\
& Sig. (2-tailed) & .002 & \\
& $\mathrm{~N}$ & 52 & 52 \\
\hline
\end{tabular}

** Correlation is significant at the 0.01 level (2-tiled), margin error 0.05

Correlation value 0.468 with probability 0.003 and probability value smaller than the error rate $5 \%$ $(0.001<0.05)$, it can be concluded there is a correlation between Unit Business and Members' Satisfaction. The coefficient is positive indicated the unidirectional relationship, means if the higher level of Training \& Education thus higher level on Members' Satisfaction, otherwise if the lower level on Training \& Education thus the lower level on Members' Satisfaction

Cohesiveness and Members' Satisfaction

Table 7: Correlation between Cohesiveness and Members' Satisfaction

\begin{tabular}{llll}
\hline & & Cohesiveness & \multicolumn{1}{c}{$\begin{array}{l}\text { Members' } \\
\text { Satisfaction }\end{array}$} \\
\hline Cohesiveness & Pearson Correlation & 1 & $.451^{* *}$ \\
& Sig. (2-tailed) & & .003 \\
Members' Satisfaction & $\mathrm{N}$ & 52 & 52 \\
& Pearson Correlation & $.451^{* *}$ & 1 \\
& Sig. (2-tailed) & .003 & \\
& $\mathrm{~N}$ & 52 & 52 \\
\hline
\end{tabular}

** Correlation is significant at the 0.01 level (2-tiled), margin error 0.05

Correlation value 0.451 with probability 0.003 and probability value smaller than the error rate $5 \%$ $(0.001<0.05)$, it can be concluded there is a correlation between Cohesiveness and Members' Satisfaction. The coefficient is positive indicated the unidirectional relationship, means if the higher level of Cohesiveness thus higher level on Members' Satisfaction, otherwise if the lower level on Cohesiveness thus the lower level on Members' Satisfaction.

Discussion: Hasibuan (2007) suggested that job satisfaction is the emotional attitude of fun and loves his job, employees' satisfaction is very important and should be created so that morale, dedication, love, and discipline of employees will be increased and finally describe the organization performance. This study is consistent with Robbins (2001) that employees were satisfied since of officers' attention, getting decent salaries, adequate work place facilities and constructive efforts to improve abilities, thus supported this finding that Management Control relating to Members' Satisfaction. Several researchers supported this study such as Lisbijanto (2013) concluded that employees' satisfaction of Worker Cooperatives influenced by control, promotion, salary and colleagues; Wong \& Page (2003) suggested that leaders who serve sincerely will motivate employees to work happily, and the result of work will lead to satisfaction, and strengthen this 
study that Boards' Performance correlated to Members' Satisfaction, but this research did not appropriate with Stringer \& Didham (2011), their finding proved that extrinsic motivation and job satisfaction are negatively associated, although finally intrinsic motivation is positively associated with job satisfaction. Their finding consistent with the "crowding-in" argument (Frey, 1997). Several studies have found a very positive relationship between a person's willingness to participate in quality improvement efforts and Organization Commitment (Meyer \& Allen, 1988; Gaertner \& Nollen, 1989), and organizational participation and a willingness to improve have also been linked in several studies to superior customer service (Tornow \& Wiley, 1990), lastly, four studies of organization commitment and work ethic indicated correlations of 0.21 to 0.43 (Morrow \& McElroy, 1987; Brooke et al., 1988), therefore supported this finding that Well-controlled Administration relating to Members' Satisfaction.

Kominis \& Emmanuel $(2005,2007)$; and Merchant et al., (2003) stated that incentive systems are related to satisfaction. Expectancy theory, as developed by Porter and Lawler (1968), argued that a pay-forperformance system influences job satisfaction (Ferris, 1977; Igalens \& Roussel, 1999), therefore suggested this research that Capital Structure relating to Members' Satisfaction. Emery \& Barker (2007) concluded that the Organizational Commitment of contact personnel relates significantly to Customer Satisfaction, and Customer Satisfaction related significantly to departmental profit, thus appropriate with this research that Unit Business related to Members' Satisfaction, although Organization Commitment did not related significantly to profit. Deluga \& Souza (1991) researched the positive relationship between supervisor leadership training skills and job satisfaction in law enforcement, but leadership training for supervisors and the resulting level of job satisfaction for subordinates is lacking. DeSpain (2008) suggested that Leadership Training and Job Satisfaction were proved correlated when analyzed by using statistical tools and this research found Education \& Training correlated to Members' Satisfaction. Gilbert \& Tang (1998) proved that age, marital status, and group cohesion were positively associated with organizational trust. They continued that organizational trust is a feeling of confidence and support in an employer; it is the belief that an employer will be straight forward and will follow through on commitments. Trust is a significant predictor of satisfaction with supervision and performance appraisal. Karl \& Sutton (1998) added that pro-social "citizenship" behaviors such as helping coworkers, helping customers, and being more cooperative will result in optimum job satisfaction and productivity, therefore supported the finding that Cohesiveness related to Members' Satisfaction.

\section{Conclusion}

Several conclusions can be obtained as follow: (1) there is correlations of Management Control, Boards' Performance, Well-controlled Administration, Capital Structure, Unit Business, Training \& Education, and Cohesiveness on Members' Satisfaction: the higher Management Control, it could lead to higher Members' Satisfaction; the higher Boards' Performance, it could lead to higher Members' Satisfaction; the higher Wellcontrolled Administration, it could lead to higher Members' Satisfaction; the higher Capital Structure, it could lead to higher Members' Satisfaction; the higher Unit Business, it could lead to higher Members' Satisfaction; the higher Training \& Education, it could lead to higher Members' Satisfaction; the higher Cohesiveness it could lead to higher Members' Satisfaction, (2) Cooperatives' Principle is an abstract vision which must be implemented and can be measured in real activities by the board; (3) All accredited cooperatives conducted members' meeting and education \& training, voluntary and open membership, democratic member control, autonomy and independence, and concern for community

Recommendations: The future research should: (1) add the new relationship between Organization Performance and Job Satisfaction as Lisbijanto stated (2013) Job Satisfaction not influenced by Boards' Performance but instead Organization Performance influenced by Job Satisfaction, (2) use longitudinal data to make deeper and enhancing of study, (3) boards and managers should work hard to increase sales of products on the cooperative members, since there were $92 \%$ of cooperatives sold the products to non members; (4) almost the products were not specific products and many competitors, therefore cooperatives must innovate or add new products to boost the progress of cooperatives, (5) to promote cooperatives principles identity in a wider community, cooperatives need brochures and leaflets containing the summary outline of cooperatives' principles; (6) there were employees who lack of duties and responsibilities thus 
need training to increase the understanding of technical skills, such as customer service, accounting for cooperatives, and selling skills.

\section{References}

Altay, A. (2007). Relation of Social Capital and Poverty. Ege Akademik Bakış / Ege Academic Review, 7(1), 337362.

Brooke, P. P., Russel, D. W. \& Price, J. L. (1998). Discriminant Validation of Measures of Job Satisfaction, Job Involvement, and Organizational Commitment. Journal of Spplied Psychology, 73, 139-145

Deluga, R. J. \& Souza, J. (1991). The Effects of Transformational and Transactional Leadership Styles on The Influencing Behavior of Subordinate Police Officers. Journal of Occupational Psychology, 1(3), 49-55.

DeSpain, L. (2008). The Relationship Between Police Supervisor Training and Job Satisfaction Levels As Reported By Patrol Officers. Dissertation. USA: University of Phoenix.

Dinamika, G. (2010). Research on Women Cooperatives' Performance. Cooperatives, Small Medium and Enterprises East Java Province.

Emery, C. R. \& Barker, K. J. (2007). Effect of Commitment, Job Involvement and Teams on Customer Satisfaction and Profit. Team Performance Management, 13 (3/4), 90-101.

Ferris, K. R. (1977). A Test of Expectancy Theory of Motivation in An Accounting Environment. The Accounting Review, 52(3), 605-615.

Frey, B. S. (1997). On the Relationship between Intrinsic and Extrinsic Work Motivation. International Journal of Industrial Organization, 15(4), 427-439.

Gaertner, K. N. \& Nollen, S. D. (1989). Career Experiences, Perceptions of Employment Practices, and Psychological Commitment to the Organization. Human Relations, 42, 975-991.

Gilbert, J. A. \& Tang, L. P. (1998). An Examination of Organizational Trust Antecedents. Public Personnel Management, 27(3), 321.

Hansen, G. B. (1993). The Role of Cooperatives in the Promotion of Employment and Income. Paper. Geneva. Switzerland.

Hasibuan, M. (2007). Human Resources Management. Indonesia: Bumi Aksara.

Herzberg, F. (2003). One More Time: How Do You Motivate Employees? Harvard Business Review, 81(1), 5362.

ICA. (1995). Statement on the Cooperative Identity: International Cooperative Alliance. The Cooperative Identity, 88(4), 85f.

Igalens, J. \& Roussel, P. (1999). A Study of the Relationship between Compensation Package Work Motivation and Job Satisfaction. Journal of Organizational Behavior, 20(7), 1003-1025.

ILO. (1992). Recommendation 127.

Indonesian Cooperatives Constitution. (1992). Article 4, No. 25, Functions and Roles of Cooperatives.

Karl, K. A. \& Sutton, C. L. (1998). Job Values in Today's Workforce: a Comparison of Public and Private Sector Employees. Public Personnel Management, 27, 515-528.

Kominis, G. \& Emmanuel, C. R. (2005). Exploring the Reward Preferences of Middle Level Managers. Qualitative Research in Accounting \& Management, 2(1), 54-76.

Kominis, G. \& Emmanuel, C. R. (2007). The Expectancy-Valence Theory Revisited: Developing an Extended Model of Managerial Motivation. Journal Management Accounting Research, 18(1), 49-75.

Kostekli, S. I. (2005). Employment Strategies and an Employment Model Proposal for Turkey, Istanbul University Social Sciences Institute. Department of Labour Economics and Industrial Relations. Doctoral Thesis. Istanbul.

Kreitner, R. \& Kinicki, A. (2005). Organizational Behavior, 5th Edition. Jakarta: Salemba Empat.

Krivokapic-Skoko, B. (2002). The Concept and Classifications of Agricultural Co-operatives. ACCORD Paper No. 8. Charles Stuart University, Bathurst.

Lisbijanto, H. (2013). Influence of Servant Leadership and Organization Culture on Organization Performance through Job Satisfaction at Employees' Cooperatives East Java. Surabaya: Cooperatives Small Medium Enterprises Office.

Maslow, A. H. (1954). Motivation and Personality. New York, NY: Harper \& Row.

Merchant, K. A., Van der Stede, W. \& Zheng, L. (2003). Disciplinary Constraints on the Advancement of Knowledge: The Case of Organizational Incentive Systems. Accounting, Organizations and Society, 28 (2/3), 251-286. 
Meyer, J. P. \& Allen, N. J. (1988). Links between Work Experiences and Organizational Commitment during the First Year of Employment: A Longitudinal Analysis. Journal of Occupational Psychology, 61(3), 195209.

Morrow, P. C. \& McElroy, J. C. (1987). Work Commitment and Job Satisfaction over Three Career Stages. Journal Vocational Behavior, 30(3), 330-346.

Porter, L. W. \& Lawler, E. E. III. (1968). Managerial Attitudes and Performance. IL: R.D. Irwin, Homewood.

Rachbini, D. J. (1988). Cooperatives: Business or Political Approach. Kompas March 5, 1988, p. 05.

Robbins, S. P. (2001). Organizational Behavior: Application of Controversial Concept. Book 2. Jakarta: PT. Prenhallindo.

Robbins, S. P. \& Judge, T. A. (2009). Organizational Behavior. Book 1, 12th Ed. Translated by Angelica, D., Cahyani, R., Rosyid, A. Jakarta: Salemba Empat.

Stringer, C. \& Didham, J. (2011). Motivation, Pay Satisfaction, and Job Satisfaction of Front-line Employees. Qualitative Research in Accounting \& Management, 8(2), 161-179.

Tietjen, M. A. \& Myers, R. M. (1998). Motivation and Job Satisfaction. Management Decision, 36(4), 226-231.

Tornow, W. W. \& Wiley, J. W. (1990). Service Quality and Management Practices: A Look at Employee Attitudes, Customer Satisfaction, and Bottom-line Consequences. Human Resource Planning, 14(2), 105-115.

Wissman, R. A. (1997). Marketing Coordination in Agricultural Cooperatives. Rural Business-Cooperative Service, Research Report 159. USDA.

Wong, P. \& Page, D. (2003) Servant Leadership: An Apponent Process Model and Revised Servant Leadership Profile. Servant Leadership Roundtable, 3(1), 1-13. 